\title{
Exploring the skills, knowledge and attitudes of successful female entrepreneurs in Ghana
}

\author{
Samuel C.K. Buame, Nyuieko A. Asempa and George Acheampong*
}

University of Ghana Business School, Legon, Ghana

\begin{tabular}{l}
\hline C H R O N I C L E \\
\hline Article history: \\
Received September 28, 2012 \\
Received in revised format \\
19 November 2012 \\
Accepted 20 November 2012 \\
Available online \\
November 272012 \\
\hline Keywords: \\
Entrepreneurship \\
Women \\
Gender \\
Ghana \\
Skills \\
Attitudes \\
\hline
\end{tabular}

\section{A B S T R A C T}

\begin{abstract}
The Indigenous Ghanaian woman entrepreneur, this study found exhibits many similarities with their counterparts in other countries in terms of their personality traits. However, they differed in other aspects such as their educational backgrounds and modes of entrepreneurial skills acquisition. Through their entrepreneurial activities the women have made substantial contributions to the economic growth of Ghana in terms of innovation, job creation, and reduction in poverty and unemployment. Using a survey methodology, this study concludes that to succeed as a female entrepreneur in Ghana, one requires some specific knowledge, skills and attitudes.
\end{abstract}

(c) 2013 Growing Science Ltd. All rights reserved.

\section{Introduction}

Encouraging entrepreneurship has become an accepted wisdom in economic management and government policy. Ranging from policy, education, provision of finance and various innovative ways to encourage entrepreneurship, individuals including females are venturing into enterprise. According to Jack and Anderson (1999), those who succeed in entrepreneurship are 'reflective practitioners' and they consider to be individuals whose knowledge and critical abilities are capable not only of starting new businesses but also of ensuring the continuing viability of businesses by enhancing the capacity for them to develop through a richer understanding of the entrepreneurial process. Livesay (1982) suggested that "successful entrepreneurship is an art form as much as, or perhaps more than, it is an economic activity, and as such it is as difficult as any other artistic activity to explain in terms of original method or environmental influence” (p.13). However, as Jack and Anderson (1999) indicated, entrepreneurship can be conceptualised as a process, which is both an art and a science and the successful experiences developed into theory and this theory will help to bridge 
the abyss. This study, therefore, ventures to collect the experiences of successful female Ghanaian entrepreneur in relationship with their knowledge, skills and attitudes. According to the Ghana Living Standards Survey 5 (2008), the adult female literacy rate in Ghana currently is estimated at 65.9 per cent compared to 16.6 per cent in 1970. The current ratio of young literate females to males in the age range of 15-24 is also estimated at 95.7 per cent and the gender parity index at the primary and secondary levels is 97 per cent and 87 per cent, respectively. Thus, the female labour force participation rate in Ghana is estimated 50.1 per cent and women account for about 50.2 per cent of the entire population of Ghana. This means that women in Ghana probably constitute half of the entire labour force and are contributing to national output growth even though this is often not measured. This notwithstanding, most economically active women in Ghana operate in the informal economy, where they outnumber men, and are particularly involved in various micro-enterprises and retail trade. (Voices of Women Entrepreneurs in Ghana, 2007). In Ghana, the highly significant number of entrepreneurs is female, there is academic ignorance as to how and why small firms involving females succeed and fail (Vinten \& Alcock, 2004). The required and favourable skill, knowledge and attitude to succeed as a female entrepreneur are not documented.

The general objective of this research is to explore and account for the factors responsible for success in enterprise from the perspective of the Ghanaian female entrepreneur. In order to satisfy this objective, the study will specifically assess skills required succeeding as a female entrepreneur in Ghana. A further Examining of the relevant knowledge required of a female entrepreneur to succeed will explored and finally identify those attitudes from the Ghanaian context that favour a female in enterprise. Empirical analysis of the gender and economic growth nexus for Ghana suggests that a significant increase in the female literacy rate could produce an increase in real output growth by about one-half. In other words, a significant improvement in gender equity, be it in terms of human capital accumulation, women's economic participation or otherwise will have significant beneficial effects on economic growth rates amounting to about 2.5 percent a year. This is significant for the quest to scale up growth rates to 8-10 percent in order to become a middle income country within 10 years and to meet the Millennium Development Goals (MDGs). Therefore, a study of this sort that holds the potency to inform entrepreneurship without which the economy will perish is of agent significance. In order to satisfy this objective, the study will specifically observe the following:

1 Assess skills required succeeding as a female entrepreneur in Ghana.

2 Examine the relevant knowledge required of a female entrepreneur to succeed.

3 Identify those attitudes from the Ghanaian context that favour a female in enterprise.

The study is limited women entrepreneurs at various locations in the Accra Metropolis since it represents the central economic hub of the country.

\section{The Entrepreneurship Literature}

According to Raposo et al. (2008), although there is no unanimous definition to characterize the entrepreneur some agreements on the attached characteristics seem to exist (Davidsson, 1989; Boydston et al., 2000; Beverland \& Lockshin, 2001). Most of the literature associates the following types of characteristics to entrepreneurs (Raposo Paco \& Ferreira (2008) :

- Individual attributes;

Simpson et al. (2004) suggested that the entrepreneurial characteristics that contribute to small business success are to do with technical and mental ability, human relations skills, high achievement drive and creativity.

- Risk taking; 
This variable refers to risk acceptation when entering an activity and it is associated with the probability of an activity having less than 100 per cent success (Kuip \& Verheul, 2003). Davidsson (1989) asserted that if the aspirations are sufficiently accomplished, the entrepreneurs may simply stop taking higher risks.

- $\quad$ Need for achievement;

There is a strong sustenance on the relationship between need for achievement and entrepreneur's behaviour on individual level (Davidsson, 1989).

- Locus of control;

Locus of control is the degree in which the individual believes that the reinforcements are dependent on his behaviour. These individuals believe the accomplishment of a goal or purpose depends on his/her own ability and actions rather than luck or other people’ efforts (Kuip \& Verheul, 2003).

- Profit motivation

In early development phases, economic motivation may completely dominate behaviour while other objectives may be sacrificed as a consequence to profit prosecution. However, in later phases such options are not made so immediately.

- Creativity

This characteristic is related to the development of new methods instead of using a standard procedure. As components of creativity, the fluidity (capacity to produce a large amount of ideas), originality (capacity to produce new and unusual ideas), flexibility (ability to "jump" between different approaches) and innovation (ability to define or understand something atypically) can be pointed (Torrance, 1967).

- Other motivational factors and personal values

Some characteristics are recurrent in reviewed literature. One is the need for autonomy and independence. This need refers to the desire to control and being independent, and the fear of external control. Individuals possessing a high need for autonomy consider individualism and freedom important and are opposed to rules, procedures and social regulations (Kirby, 2003).

\subsection{The Characteristics of the Entrepreneur and Success}

The external environment also has a big impact on the success of the business, they agree with Curran et al. (1986). Curran et al. (1986) argued that it is a combination of the knowledge, experiences and personality, and the way in which they are affected by the outside influences of society and the environment, that go together to make a successful entrepreneur. It has also been suggested that one of the main success factors relates to the interaction of the entrepreneur with the delivery of the service (Beaver, 2002 cited in Simpson, Tuck \& Bellamy, 2004). Simpson et al. (2004) posit as Nandram (2002) that in order to be successful the entrepreneur must have a combination of attributes and skills including being goal-oriented, decisive, pragmatic, resolute, flexible and self-confident.

Sourcing Hodgetts and Kuratko (1992), Also that setting up a business for "positive reasons" such as to be independent, to be creative, to do enjoyable work is associated with survival of the small firm. While those setting up for negative reasons such as to exploit a market opportunity or meet a 
perceived service need, reduced the probability of survival (Watson et al., 1998 in Simpson et al., 2004). Mukhtar (1998 in Simpson et al., 2004) examined the differences between male and female owner-managed small businesses in the UK, to try to establish whether female business owners constituted a distinct entrepreneurial group. Mukhtar (1998) focused on established businesses and found that male and female business owners have different motivations and make different choices, resulting in different business characteristics. Mukhtar (1998, p. 48) found that the decision-making of the two genders differed, concluding that they "exhibit different forms of entrepreneurialism".

\subsection{The motivations of women entrepreneurs}

According to Bruni et al. (2004), the dominant discourse regarding the reasons why women may decide to start up a business distinguishes between "compulsion" factors (which constrain women more out of necessity than choice) and positive or "attraction" factors (which induce women to see entrepreneurship as an opportunity). Bruni et al. (2004) presented attraction represented by motives such as those outlined in Monaci (1997), a way to supplement an inadequate household income; or as a solution for entering in an activity in which formal selection criteria (qualifications, experience and gender) seem less stringent; as well as a strategy to obtain greater margins of flexibility and discretion. On the other side, compulsion is depicted as a search for independence and autonomy in work; a search for professional self-fulfilment; a search for income; the pursuit of a social mission (e.g. the social integration of the more vulnerable members of society). In general, Bruni et al. (2004) state, "the entry of women into entrepreneurship seems to be a complex mix of constraints and opportunities, of external coercions and subjective aspirations. Yet, seen in deconstructive light, the interweaving of availability for the market and for the family which places adult women with family responsibilities in two systems (that are in fact interdependent though symbolically separate) is a normative model that produces drudgery, coercion, restrictions of time and cleavages of identity”. At the same time, those women able to cope with these constraints are represented as skilled in the management of flexibility and relational resources. A survey administered nationally to 784 young Australians (ranging from 15 to 24 years of age) sought to gauge young people's attitudes to entrepreneurialism (DETYA, 2001). The study found that four personal qualities were regarded as essential to the success of an entrepreneur: determination and persistence; confidence; being good with people; enthusiasm and energy. Creativity and the ability to be innovative; accepting of the possibility of loss in order to have a chance of succeeding; and intelligence were seen as slightly less critical, but nevertheless important. This study concurs with Ward (2004) and other works from the perspectives presented above to assess enterprise skills in Ghanaian women entrepreneurs as composite of skills, attributes, qualities and beliefs that are acquired through the combination of curriculum-based learning, observation of role models and life experience.

\section{Methodology}

The study adopts an exploratory research methodology combining both quantitative and qualitative techniques. The design of the study was cross-sectional (one off). Time and financial resources play a number of roles in the design and execution of research. A structured questionnaire was design to assess the sample based of stated dimensions in literature. In structuring the study, the researcher consulted a wide array of material in the subject area, which presented in the literature review chapter. Based on information from previous studies, the survey research was chosen.

\subsection{Selection of respondents}

To facilitate the selection of the sample size, a Non-Probability purposive sampling technique was adopted. This was to enable easy accessibility and convenience due to time constraint. This means that data collection was more subjective. A total of fifty questionnaires were sent out. Out of these thirty were returned and used culminating into a response rate of $60 \%$ which is relatively high 


\subsection{Structured interview approach}

The questionnaire was made of mostly closed-ended questions. This was done so as to facilitate administration, coding and analysis. The data is submitted to several statistical treatments such as analysis of variance and correlation using SPSS (Statistical Package for Social Sciences). Survey method adopted.

\subsection{Quality control and sampling}

After thorough planning and designing of the study, the first field visit was made to Accra Central in an attempt to pre-test the questionnaire. Suggestions about rephrasing some of the questions to convey the intended meaning were made and also, mistakes that were identified during the pre-testing stage were corrected.

\section{Data Analysis and Finding}

\subsection{Background information}

On the ages of the women who participated in this study, it can be observed form the Table 1 below, majority of them representing $43.3 \%$ of the sample was aged between 40 and 59 . Few young females (6.7\%) entrepreneurs who were below the age 20 also participated in the study. $30 \%$ of the participants aged 20 to 39, 43.3\% aged 40 to 59 and the remaining 20\% were older than 60 . In terms of marital status, $26.7 \%$ of the participants were single, $60 \%$ were married and $13.3 \%$ were divorced. In terms of educational background, $30 \%$ of them had less than secondary education, 50\% finished secondary educational background and the remaining $20 \%$ had more than secondary educational background. $66.7 \%$ of the participants were running sole proprietorship, $16.7 \%$ were involved with Partnership and only $16.7 \%$ were running Limited liability. In our survey, $13.3 \%$ of the entrepreneur claimed they had no other choice, $13.3 \%$ selected this business by chance, $10 \%$ believed it was natural succession, $16.7 \%$ being entrepreneur was forced to them, $23.3 \%$ were informed entrepreneur and $23.3 \%$ were pure entrepreneur.

\section{Table 1}

Background information $(n=30)$

\begin{tabular}{llllll}
\hline Age of business & Percentage & Method of start & Percentage & Number of employees & Percentage \\
\hline $0-4$ & $20.0 \%$ & Started up & $80.0 \%$ & Less than 3 & $33.3 \%$ \\
$5-9$ & $43.3 \%$ & Purchased & - & $3-6$ & $36.7 \%$ \\
$10-19$ & $30.0 \%$ & Inherited & $20.0 \%$ & $6-9$ & $16.7 \%$ \\
20 and above & $6.7 \%$ & Worked as employee & - & 10 and above & $13.3 \%$ \\
\hline
\end{tabular}

As in the Table 1 above, the women entrepreneurs were mostly married (60\%), (13.3\%) however had divorced. There were also those who were not married. It was found that $30 \%$ and $20 \%$ had below secondary and tertiary education respectively. While $20 \%$ had pre secondary school education. It was observe also that the younger entrepreneur had higher education than the older once, suggesting more educated young women are venturing into entrepreneurship. Information on the businesses of the women indicates most of them have been in operation for 5-9 years (43.3\%). Also these businesses were either inherited (20.0\%) from parents or husbands or founded (80.0\%) by them. Being small to medium scale enterprises, the numbers of employees in most cases were between 3 and 6 (36.7\%).

\subsubsection{Self-awareness}

The construct, self-awareness was assessed on three elements. It can be seen from Table 2 that the respondents assessed highest their knowledge related to their emotions. On the scale from 1 to 5 this 
knowledge was usually assessed by 4.200. A relatively low standard deviation of only 0.847 proves that that the responses concentrated around the mean value and points to the uniformity of respondents. In addition, the respondents believe they know their strength and weaknesses - accurate self-assessment (assessed by 3.80 on the scale from 1 to 5). The women also rated highly their selfconfidence (assessed by 3.80 on the scale from 1 to 5), marketing (assessed by 3.698 on the scale from 1 to 5) the same score for accurate self-assessment but with a slightly higher dispersion.

\section{Table 2}

Descriptive statistics on self-awareness

\begin{tabular}{llll}
\hline Variables & $\mathrm{N}$ & Mean & Std. Deviation \\
\hline Emotional awareness & 30 & 4.2000 & .84690 \\
Accurate self-assessment & 30 & 3.8000 & .84690 \\
Self-confidence & 30 & 3.8000 & 1.12648 \\
\hline
\end{tabular}

\subsubsection{Self-regulation}

The construct, self-awareness regulation was assessed on five items. As Table 3 shows, the respondents assessed highest trustworthiness. On the scale from 1 to 5 this was usually assessed by 4.10. A relatively low standard deviation of 1.383 suggests that the responses concentrated around the mean value and points to the uniformity of respondents. Closely following in the rating is adaptability with 4.0 on a scale of 1 to 5 . Innovativeness (assessed by 3.90 on the scale from 1 to 5), conscientiousness (assessed by 3.63 on the scale from 1 to 5). The lowest assessment grades are given to self-control (assessed by 3.47 on the scale from 1 to 5 ).

Table 3

Descriptive Statistics on self-regulation

\begin{tabular}{llllll}
\hline Variables & Self-control & Trustworthiness & Conscientiousness & Adaptability & Innovativeness \\
\hline Mean & 3.4667 & 4.1000 & 3.6333 & 4.0000 & 3.9000 \\
Std. Deviation & 1.38298 & 1.18467 & 1.06620 & .98261 & 1.29588 \\
\hline
\end{tabular}

\subsubsection{Self-motivation}

Self-motivation was the next set of construct assessed. This set consists of four items presented in table 4 below. It can be seen from Table 4 that the respondents assessed highest their optimism. On the scale from 1 to 5, optimism was averagely scored 3.97. A relatively low standard deviation of only 1.07 proves that that the responses concentrated around the mean value and points to the uniformity of respondents. In addition, the respondents believe their initiative drive (assessed by 3.83 on the scale from 1 to 5 ) is very key in their success at entrepreneurship. The women also rated on the high achievement drive (assessed by 3.77 on the scale from 1 to 5 ) and commitment (assessed by 3.70 on the scale from 1 to 5 ).

\section{Table 4}

Descriptive Statistics on self-motivation

\begin{tabular}{llll}
\hline Variables & $\mathrm{N}$ & Mean & Std. Deviation \\
\hline Achievement drive & 30 & 3.7667 & 1.07265 \\
Commitment & 30 & 3.7000 & 1.11880 \\
Initiative drive & 30 & 3.8333 & .98553 \\
Optimism & 30 & 3.9667 & .96431 \\
\hline
\end{tabular}

\subsubsection{Social awareness}

The social-awareness construct was assessed on five items. As Table 5 shows, the sense of others' feelings and perspectives - empathy came highest rated by the respondents. On the scale from 1 to 5 this was usually assessed by 4.37. A relatively low standard deviation of 0.795 suggests that the responses concentrated around the mean value and points to the uniformity of respondents. Following 
empathy in the rating were developing others and leveraging diversity (both assessed by 3.90 on the scale from 1 to 5) but with different dispersions of 1.06 and 0.99 respectively. The standard deviations of both items indicate the responses were relative around the means. The lowest assessment grades are given to political awareness (assessed by 3.83 on the scale from 1 to 5) and service orientation (assessed by 3.80 on the scale from 1 to 5).

Table 5

Descriptive Statistics on social awareness

\begin{tabular}{llll}
\hline Variables & $\mathrm{N}$ & Mean & Std. Deviation \\
\hline Empathy & 30 & 4.3667 & .76489 \\
Service orientation & 30 & 3.8000 & 1.03057 \\
Developing others & 30 & 3.9000 & 1.06188 \\
Leveraging diversity & 30 & 3.9000 & .99481 \\
Political awareness & 30 & 3.8333 & .94989 \\
\hline
\end{tabular}

\subsubsection{Social skills}

With regard to the question about social skills, the respondents most frequently assessed the statement that they are good at wielding effective tactics for persuasion - influence others (assessed with 4.13 on the scale from 1 to 5) and the statement that they are good at inspiring and guiding groups and people - leadership (assessed with 4.00 on the scale from 1 to 5). The least scored statement was that they are good at nurturing instrumental relationships- building bonds (assessed with 3.46 on the scale from 1 to 5). The details on the assessment of the remaining items under social skills are shown in table 6 below.

Table 6

Descriptive Statistics on social skills

\begin{tabular}{lllc}
\hline Variables & $\mathrm{N}$ & Mean & Std. Deviation \\
\hline Influence & 30 & 4.1333 & 1.07425 \\
Communication & 30 & 3.7667 & 1.07265 \\
Leadership & 30 & 4.0000 & .87099 \\
Change catalyst & 30 & 3.9667 & 1.21721 \\
Conflict management & 30 & 3.5676 & 1.38174 \\
Building bonds & 30 & 3.4667 & 1.33218 \\
Collaboration and cooperation & 30 & 3.9000 & 1.18467 \\
Team capabilities & 30 & 3.5677 & 1.38174 \\
\hline
\end{tabular}

\subsubsection{Business Skills}

Women's ability to perform basic business management was assessed under business skills. The women rated their financial management skills highest (assessed by 3.90 on the scale of 1 to 5) with a dispersion of 0.84 proving uniformity in their response. Their ability to define their market and market their business/ products was assessed at 3.80, pricing (assessed by 3.73) and contracting assessed at 3.7. The women rated their ability to plan the business at 3.47 on the scale. The statement on negotiating skills received the least rating under business skills (assessed by 3.27 on a scale of 1 to 5).

\section{Table 7}

Descriptive Statistics on business skills

\begin{tabular}{lccc}
\hline Variables & N & Mean & Std. Deviation \\
\hline Contracting & 30 & 3.7000 & .83666 \\
Negotiation skills & 30 & 3.2667 & .86834 \\
Pricing & 30 & 3.7333 & 1.01483 \\
Marketing & 30 & 3.8000 & 1.12648 \\
Planning & 30 & 3.4667 & 1.04166 \\
Financial management & 30 & 3.9000 & 1.09387 \\
\hline
\end{tabular}




\subsubsection{Critical success factors for entrepreneurship}

From literature reviewed, the researchers observed various factors considered critical for entrepreneurial success. In order to measure which apply to the sample of this study a list of seven commonly cited factors were list for the respondents to rank. The mean rank of these factors are computed and detailed in the table 8 below. It can be observed from table 8 that the women entrepreneurs consider "Creativity and the ability to be innovative" as the most critical factor for success in entrepreneurship. The least scored was "Accepting the possibility of loss in order to have a chance of succeeding”

\section{Table 8}

Descriptive Statistics on critical factors of entrepreneurship

\begin{tabular}{lccc}
\hline Variables & Mean & $\begin{array}{l}\text { Std. } \\
\text { Deviation }\end{array}$ & $\begin{array}{l}\text { Mean } \\
\text { Ranks }\end{array}$ \\
\hline Creativity and the ability to be innovative & 3.5333 & 2.11291 & 3.47 \\
Enthusiasm and energy & 3.7000 & 1.98529 & 3.65 \\
Intelligence & 3.7333 & 1.99885 & 3.70 \\
Determination and persistence & 4.0333 & 1.82857 & 3.97 \\
Confidence & 4.2333 & 1.69550 & 4.20 \\
Being good with people & 4.3000 & 1.95024 & 4.23 \\
Accepting the possibility of loss in order to have a chance of succeeding & 4.8000 & 2.17192 & 4.78 \\
\hline
\end{tabular}

\subsection{Inferential statistics}

This section of the analysis makes inferences from the data. The main objective of this section is to compare the constructs assessed by the women entrepreneurs, using some of the variables under background information. This is to observe any differences or similarity in the assessment of the various variables in the construct.

\subsubsection{Correlation of the six dimensions assessed}

Another set of analysis done on the data collected was to test for correlation between the various variables. This was done to assess how the variables affect each other. In their total rating, the women entrepreneurs generally assessed highly the various dimensions, with the highest being social awareness (assessed 3.96 on a scale of 1 to 5) and the least being business skills (assessed 3.61 on a scale of 1 to 5 ) as present in table 13 below.

Table 13

Descriptive Statistics

\begin{tabular}{lllllll}
\hline & Self-awareness & Self-regulation & Self-motivation & Social awareness & Social skills & Business skills \\
\hline Mean & 3.9333 & 3.8167 & 3.8167 & 3.9600 & 3.7958 & 3.6143 \\
Std. Deviation & .53534 & .52352 & .52083 & .35777 & .56523 & .25761 \\
\hline
\end{tabular}

Table 9

Cross correlations of six dimensions

\begin{tabular}{|c|c|c|c|c|c|c|}
\hline & & Self-awareness & Self-regulation & Self-motivation & Social awareness & Social skills \\
\hline \multirow[t]{2}{*}{ Self-regulation } & Pearson Correlation & -.184 & & & & \\
\hline & Sig. (2-tailed) & .331 & & & & \\
\hline \multirow[t]{2}{*}{ Self-motivation } & Pearson Correlation & -.313 & -.233 & & & \\
\hline & Sig. (2-tailed) & .092 & .216 & & & \\
\hline \multirow[t]{2}{*}{ Social awareness } & Pearson Correlation & .190 & -.069 & -.337 & & \\
\hline & Sig. (2-tailed) & .316 & .716 & .069 & & \\
\hline \multirow[t]{2}{*}{ Social skills } & Pearson Correlation & -.184 & .297 & .158 & -.016 & \\
\hline & Sig. (2-tailed) & .330 & .111 & .405 & .932 & \\
\hline \multirow[t]{2}{*}{ Business skills } & Pearson Correlation & .236 & $-.554^{* *}$ & -.086 & .254 & -.090 \\
\hline & Sig. (2-tailed) & .210 & .001 & .650 & .175 & .636 \\
\hline
\end{tabular}


Table 14 above presents the cross correlation of the various variables assessed in this study. The table also shows the significance of the correlation. It can be observed from the table 14 both positive and negative correlations are reported. A Pearson Correlation coefficient $(-0.184)$ is reported between Self-regulation and Self-awareness. The observed negative correlation suggests that, an increase in self-awareness adversely affects self-regulation of the women entrepreneurs and vice versa. This is however statistically proven insignificant since $p>0.01$ as shown in Table 14 . Self-awareness and self-motivation also recorded a negative correlation (-0.313). The negative correlation suggests, the higher a woman's self-awareness, the lower her self-motivation. This is however not statistically proven since $p>0.01$. Self-awareness against social-awareness returned a positive correlation (0.190). The positive correlation indicates the higher a woman entrepreneur's self-awareness, the higher her social-awareness and vice versa. The significance of this correlation returned a $p$-value of 0.316 . Since $p>0.01$ the correlation is statistically insignificant. Self-awareness correlated with social skills returned -0.184. A negative correlation between the two variables indicates, an increase in one leads to a decrease in the other. With $p=0.330>0.01$, the correlation can be concluded not to be statistically significant.

Self-awareness positively correlates with business skills as presented in table 14 above (0.236). Business skill here refers to the women's ability to undertake basic management such as pricing, marketing, book-keeping, and contracting and negotiation skills. The test of significant for the correlation of these two variables proves it's insignificant $(p>0.01)$. Self-regulation correlates negatively with self-motivation, social awareness as well as business skills. These suggest, the higher a woman entrepreneur's self-regulation, the lower her self-motivation, social awareness and business skills. This assertion however did not stand the statistical test for significance for self-regulation paired against self-motivation and social awareness since they both returned $p>0.01$. Against business skills however the correlation is proved significant $p<0.01$. Self-regulation against social skills on the other hand correlates positively (0.297) but statistically insignificant. Self-motivation as can be observed from table 14 above correlates negatively with social awareness. Indicating a woman entrepreneur with high scores on self-motivation will record a lower social awareness score. Selfmotivation paired against social skills and business skills however recorded positive correlations. Indicating an increase in self-motivation will come with a corresponding increase in both social skills and business skills. Statistical significance however could not be proved for the above three correlations. Social awareness correlates negatively with social skills but positively with business skills. Though both correlations do not prove statistically significant, the result suggests an increase in a woman entrepreneur's social awareness may lead to a decrease in her social skills but increase in business skills. Between social skills and business skills is recorded a statistically insignificant negative correlation.

\section{Conclusion}

The Indigenous Ghanaian woman entrepreneur this study found exhibit many similarities with their counterparts in other countries in terms of their personality traits. However, they differed in other aspects such as their educational backgrounds and modes of entrepreneurial skills acquisition. Through their entrepreneurial activities the women have made substantial contributions to the economic growth of Ghana in terms of innovation, job creation, and reduction in poverty and unemployment. This study concludes that there are skills, knowledge and attitudes required succeeding as a female entrepreneur in Ghana. These skills, knowledge and attitudes are not mostly acquired through formal education but rather self-knowledge, social knowledge, inter-personal skills and experience from the society. Basic business skills are required to succeed as female entrepreneur. Again, in order to be successful, the woman entrepreneur must have a combination of attributes and skills including being goal-oriented, decisive, pragmatic, resolute, flexible and self-confident. The entrepreneurial women are working on a very limited scale subject to little or no knowledge and lack of required resources. The government has not played a significant role in providing them academic, financial technical support needed to promote women entrepreneurship. Support on this level is 
highly needed by the entrepreneurial women in order to grow their businesses and reach the international markets. Both the young and old entrepreneurial women should work with mutual collaboration to meet the challenges of male dominated society.

\section{References}

Beaver, G. (2002). Small Business Entrepreneurship and Enterprise Development. Pearson Education.

Boydston, M., Hopper, L., \& Wright, A. (2000). Locus of control and entrepreneurs in a small town. San Antonio, TX, Proceedings of the ASBE,

Bruni, A., Gherardi, S., \& Poggio, B. (2004). Gender and Entrepreneurship: An Ethnographic Approach. Routledge, London.

Curran, J., Stanworth, J., \& Watkins, D. (1986). The Survival of the Small Firm. The Economics of Survival and Entrepreneurship. Vol. 1, Gower Publishing, Aldershot.

Davidsson, P. (1989). Continued Entrepreneurship and Small Firm Growth. Stockholm School of Economics, Stockholm, Sweden.

Harlow.Begley, T. \& Boyd, D. (1987). Psychological characteristics associated with performance in entrepreneurial firms and smaller businesses. Journal of Business Venturing, 2(1), 79-93.

Hill, J., \& McGowan, P. (1999). A qualitative approach to developing small firm marketing planning competencies. Qualitative Market Research: An International Journal, 2(3), 167-175.

Hodgetts, R.M., \& Kuratko, D.F. (1992). Effective Small Business Management, $4^{\text {th }}$ ed., Harcourt Brace Jovanovich, San Diego, FL.

Kuip, I., \& Verheul, I. (2003). Early development of entrepreneurial qualities: the role of initial education. Working Paper, SCALES-paper N200311

Livesay, H. C. (1982). Entrepreneurial History In Kent. Encyclopaedia of Entrepreneurship, Englewood cliffs. Prentice-Hall.

Lockshin, L. S. (2001). Organizational life cycles in small New Zealand wineries. Journal of Small Business Management, 39(4), 354-362.

Monaci, M. (1997). Genere e Organizzazione, Guerini e Associati. Milan.

Mukhtar, S.M. (1998). Business characteristics of male and female small and medium enterprises in the UK: implications for gender-based entrepreneurialism and business competence development. British Journal of Management, 9(1), 41-51.

Nandram, S.S. (2002). Behavioural attributes of entrepreneurial success and failure: new perspectives gained from critical incident technique. Proceedings of the Small Business and Entrepreneurship Development Conference - Theoretical and Empirical Advances in International Entrepreneurship, The University of Nottingham, 15-16 April, European Research Press, Shipley, 321-30.

Orhan, M., \& Scott, D. (2001). Why women enter into entrepreneurship: An exploratory model. Women in Management Review, 16(5/6), 232-244.

Perren, L. (1999). Factors in the growth of micro-enterprises (part 1): developing a framework. Journal of Small Business and Enterprise Development, 6(4), 366-85.

Perren, L. (2000). Factors in the growth of micro-enterprises (part 2): exploring the implications. Journal of Small Business and Enterprise Development, 7(1), 58-68.

Raposo, M., Paço, A., \& Ferreira, J. (2008). Entrepreneur's profile: a taxonomy of attributes and motivations of university students. Journal of Small Business and Enterprise Development, 15(2), $405-418$.

Revans, R. (1971), Developing Effective Managers, Longman, Harlow.

Rosener, J. B. (1990). Ways women lead. Harvard Business Review, 68, 119-20.

Simpson, M., Tuck, N., \& Bellamy, S. (2004). Small business success factors: the role of education and training. Education Training. Emerald Group Publishing Limited, 46(8/9), 481-491.

Torrance, E. P. (1987). Teaching for creativity. In Isaken, S. G. (Ed) Frontiers of creativity research. Bearly Buffalo, New York.

Vinten, G., \& Alcock, S. (2004). Entrepreneuring in education. The International Journal of Education Management, 18(3), 188-95. 